\title{
PENGEMBANGAN MULTIMEDIA PEMBELAJARAN MATEMATIKA PADA MATERI BANGUN RUANG SISI DATAR UNTUK SISWA SMP KELAS VIII
}

\author{
Albertus Nur Cahya Nugraha, Ali Muhtadi \\ Program Studi Teknologi Pembelajaran PPs UNY, Universitas Negeri Yogyakarta \\ cahyo.nugrah4@gmail.com, ali_bintangku@yahoo.co.id
}

\begin{abstract}
Abstrak
Penelitian ini bertujuan untuk menghasilkan produk multimedia pembelajaran matematika pada materi bangun ruang sisi datar untuk siswa SMP kelas VIII Semester II yang layak, dan mendeskripsikan tingkat keefektifan penggunaan multimedia pembelajaran dan peningkatan ketuntasan belajar siswa dalam pencapaian tujuan kognitif pembelajaran matematika pada materi bangun ruang sisi datar setelah menggunakan multimedia pembelajaran. Penelitian ini menggunakan metode penelitian dan pengembangan (R\&D). Tahapan dalam penelitian ini terdiri dari: tahap perencanaan, tahap desain dan tahap pengembangan. Hasil penelitian menunjukkan: produk multimedia yang dihasilkan layak sebagai media pembelajaran matematika materi bangun ruang sisi datar berdasarkan validasi oleh ahli materi pada Uji Alfa dengan hasil penilaian sangat baik, validasi oleh ahli media pada Uji Alfa dengan hasil penilaian sangat baik, dan penilaian oleh 32 orang siswa pada Uji Beta dengan hasil sangat baik. Produk multimedia pembelajaran matematika pada materi bangun ruang sisi datar efektif meningkatkan hasil belajar siswa dengan kriteria sedang dan meningkatkan ketuntasan belajar siswa setelah menggunakan produk multimedia pembelajaran matematika bangun ruang sisi datar dengan rerata pretes 4,96 dan postes diperoleh rerata 7,4. Pencapaian KKM siswa pada saat pretes dinyatakan tidak tuntas $100 \%$, sedangkan pada saat postes dinyatakan tuntas $75 \%$.
\end{abstract}

Kata kunci: multimedia, pembelajaran matematika, bangun ruang sisi datar

\section{DEVELOPING MATHEMATICS INSTRUCTIONAL MULTIMEDIA ON THE PLANE TOPIC FOR GRADE VIII STUDENTS OF JUNIOR HIGH SCHOOL}

\author{
Albertus Nur Cahya Nugraha, Ali Muhtadi \\ Universitas Negeri Yogyakarta \\ cahyo.nugrah4@gmail.com, ali_bintangku@yahoo.co.id
}

\begin{abstract}
This research aims to: produce viable mathematics learning multimedia on the plane topic for junior high school students of class VIII, Semester II; and describe the effectiveness of the instructional multimedia use and the increase of students' mastery learning in mathematics learning achievement of cognitive goals on the plane topic after the use of the multimedia. This research usedthe method of research and development (RED). The stages in this study consisted of: (1) planning stage, designing stage, and development stage. The results show: the produced multimedia is viable as mathematics instructional media on the plane topic as validated by the subject material experts based on Alfa Test with very good results of the assessment. The validation by media experts on Alfa Test shows very good results of the assessment, and assessment by 32 students in the Beta Test shows very good results, the produced mathematics learning multimedia on the flat space material can effectively improve students' learning outcomes at average level and to improve the students' learning completeness criteria after learning mathematics using the produced multimedia with an average pretest score of 4.96 and posttest score of 7.4. The students' scores were 100\% below the passing grade (KKM) at the pretest while at the post test $75 \%$ of the students completed the test.
\end{abstract}

Keywords: multimedia, learning mathematics, flat space material 


\section{Pendahuluan}

Dalam perkembangan ilmu pengetahuan dan teknologi (IPTEK) sekarang ini tidak dapat dipungkiri bahwa matematika memegang peranan penting dalam bidang pendidikan. Adams \& Hamm (2010, p.67) menyatakan bahwa matematika adalah

The science of numbers and their operations, interrelations, combinations, abstractions, and space configurations. The study of abstract structure is central to math. Also, structure, measurement, estimation, generalizations, and probability play a role in math-based inquiry.

Pernyataan di atas berarti bahwa matematika adalah ilmu pengetahuan tentang bilangan dan operasinya, hubungan, kombinasi, abstraksi dan konfigurasi ruang. Studi struktur abstrak merupakan pusat dari matematika. Struktur, pengukuran, estimasi, generalisasi dan peluang memainkan matematika berbasis penemuan. Matematika merupakan ilmu yang bersifat universal yang mendasari perkembangan teknologi modern. Perkembangan yang sangat pesat di bidang teknologi informasi dan komunikasi dewasa ini dilandasi oleh perkembangan matematika di bidang bilangan, aljabar maupun geometri. Untuk dapat menguasai dan menciptakan teknologi di masa depan diperlukan penguasaan matematika yang kuat. Mata pelajaran matematika diberikan kepada semua siswa sejak dari sekolah dasar, untuk membekali siswa agar mempunyai kemampuan berpikir logis, analitis, sistematis, kritis, kreatif serta kemampuan bekerja sama. Kompetensi tersebut diperlukan agar siswa memiliki kemampuan, memperoleh, mengelola dan memanfaatkan informasi pada keadaan yang selalu berubah, tidak pasti dan kompetitif di masa datang dalam memasuki era globalisasi. Namun matematika yang diajarkan pada jenjang SD, SMP, SMA maupun perguruan tinggi selalu menjadi bahan kajian. Hal ini ditandai dengan masih terdapat siswa yang mengalami kesulitan dalam mempelajari matematika sesuai dengan pengalaman peneliti pada bulan Desember 2011 saat mengajar matematika di SMP Yos Sudarso Bandung.

Hasil diskusi dengan guru Matematika di SMP Stella Duce 2 Yogyakarta kelas VIII pada bulan November 2013, menguraikan penyebab kesulitan siswa dalam memahami bangun ruang sisi datar. Pertama, selama ini siswa di sekolah dasar lebih banyak belajar tentang bidang datar sehingga terdapat peralihan/transisi untuk belajar bangun ruang. Hal demikian sering mengakibatkan miskonsepsi dan kesalahpahaman terhadap istilah-istilah dalam bangun ruang sisi datar. Kedua, rumusrumus seperti volum atau luas permukaan di Sekolah Dasar hanya diberikan saja secara langsung dan dihafal, tanpa proses menemukan sendiri sehingga pembelajaran tersebut tidak bermakna dan menyulitkan siswa untuk memahami atau mengingat rumus-rumus tersebut. Ketiga, proses pembelajaran yang dilakukan selama ini oleh guru-guru termasuk guru mapel, masih secara ceramah meskipun kadangkadang membawa alat peraga berupa kerangka model balok atau kubus, guru tidak melibatkan siswa untuk menunjuk secara langsung pada model tersebut pada bagian sisi, rusuk, titik sudut, diagonal bidang, diagonal ruang maupun bidang diagonal. Keempat, pola pengajaran selama ini masih dengan tahapan memberikan informasi tentang materi pelajaran termasuk memotivasi secara informatif, memberikan contoh-contoh dan berikutnya latihan-latihan namun guru jarang menghubungkan materi-materi tersebut dengan kehidupan nyata sehari-hari. Hal ini dikarenakan keinginan untuk cepat menuntaskan materi sehingga dapat melanjutkan materi berikutnya yang padat.

Geometri merupakan salah satu cabang matematika yang memiliki peranan penting dalam kehidupan. Menurut Atiyah (Barmby, et al, 2009, p.121) geometri adalah bagian dari matematika yang dominan dengan ide visual. Sementara itu Herskowist (Barmby, et al, 2009, p.122) mengidentifikasi aspek spasial dan logika dari geometri. 
Selanjutnya Barmby, et al, (2009, p.122) menyimpulkan.

Geometry is combination of our perception of space and development of this visual perception to a more logical or sequential conceptualization of space.

Artinya, geometri adalah kombinasi dari persepsi tentang ruang dan pengembangan persepsi visual untuk konseptualisasi ruang yang lebih logis atau berurutan. Objek dari geometri ruang adalah benda-benda pikiran yang sifatnya abstrak. Misalnya, kubus, balok, prisma, limas dan sebagainya. Salah satu subpokok bahasan geometri dan pengukuran yang diajarkan di SMP adalah bangun ruang sisi datar yang meliputi balok, kubus, prisma dan limas. Untuk mempelajari bangun ruang sisi datar siswa dihadapkan pada benda-benda yang abstrak. Bendabenda yang abstrak itu dapat diilustrasikan dengan berbagai macam cara. Secara teoretis menurut perkembangan kognitif Piaget (Miller 2012, p.56) siswa SMP berada pada tahap formal operational. Namun, karena matematika berkaitan dengan konsep yang abstrak ternyata masih terdapat siswa yang mengalami kesulitan dalam memahami konsep yang abstrak. Hasil survey Programme for International Student Assessment (PISA) 2000/2001 menunjukkan bahwa siswa lemah dalam mempelajari materi bangun ruang, khususnya dalam pemahaman ruang dan bentuk. Sebagai contoh, siswa menghadapi kesukaran dalam membayangkan suatu kubus yang berongga di dalamnya, misalnya siswa sering mengalami kesulitan dalam memahami bagianbagian mana merupakan diagonal bidang, diagonal ruang, bidang diagonal, jaringjaring dan sebagainya. Bila dikaitkan dengan kurikulum yang berlaku, porsi materi bangun ruang memang tidak banyak dan biasanya hanya diajarkan sebagai hafalan dan perhitungan semata (Suwaji, 2008, p.1).

Berdasarkan hal di atas, untuk menciptakan pembelajaran yang menarik dan memudahkan belajar siswa sehingga mampu membangkitkan semangat belajar terdapat banyak alternatif. Antara lain yaitu dengan melengkapi sarana dan prasarana pembelajaran, serta diperkaya oleh sumber-sumber belajar yang memadai juga didukung dengan inovasi media pembelajaran. Inovasi media pembelajaran tersebut digunakan untuk meningkatkan kualitas pembelajaran. Salah satu produk teknologi yang dapat digunakan sebagai inovasi dalam pembelajaran adalah komputer. Hal tersebut sesuai dengan pernyataan Surjono (1995, p.2) bahwa komputer sebagai salah satu produk teknologi dinilai tepat digunakan sebagai alat bantu pengajaran.

Di SMP Stella Duce 2 Yogyakarta sudah memiliki fasilitas laboratorium komputer yang terdiri dari 40 buah komputer dan juga 3 buah LCD proyektor yang dapat menunjang pembelajaran. Akan tetapi guru-guru masih belum menggunakannya atau memanfaatkannya fasilitas tersebut secara maksimal dalam pembelajaran. Hal ini terlihat fasilitas tersebut hanya digunakan pada saat mata pelajaran tertentu, misalnya Bahasa Inggris dan TIK.

Komputer memberi kesempatan pada siswa untuk menyajikan input yang direspon komputer atau sebaliknya. Dalam proses berikutnya respon dapat dijadikan sebagai stimulus baru sehingga dimungkinkan adanya respon lanjutan yang akan semakin memperkuat daya ingat bagi siswa dalam konsep yang dipresentasikan. Input program dapat diciptakan secara beragam, demikian sehingga terarah pada pencapaian secara objektif pembelajaran.

Sudjana dan Rivai (2011, p.2) mengatakan bahwa media pengajaran dapat mempertinggi proses belajar siswa dalam pengajaran yang pada gilirannya diharapkan dapat mempertinggi hasil belajar yang dicapainya. Alasanya berkenaan dengan manfaat media pengajaran dalam proses belajar siswa antara lain: (1) pengajaran akan lebih menarik perhatian siswa sehingga dapat menumbuhkan motivasi belajar, (2) bahan pengajaran akan lebih jelas maknanya sehingga akan lebih dipahami oleh para siswa dan memungkinkan siswa 
menguasai tujuan pengajaran lebih baik, (3) metode mengajar akan lebih bervariasi, (4) siswa lebih banyak melakukan kegiatan belajar sebab tidak hanya mendengarkan uraian guru tetapi juga aktivitas lain seperti mengamati, melakukan, mendemonstrasikan dan lain-lain, salah satunya dengan menggunakan media pembelajaran berbasis multimedia yang disertai animasi. Menurut Sutopo (2003, p.8) untuk mengembangkan sebuah program multimedia untuk kegiatan instruksional yang baik diperlukan beberapa unsur yaitu meliputi teks, grafik, animasi, audio dan link.

Teknologi multimedia mempunyai keunggulan dibandingkan dengan media alat peraga yang berupa kerangka model balok atau kubus. Hal ini karena multimedia menggabungkan sepenuhnya teknologi komputer, sistem video dan sistem audio untuk mendapat kombinasi yang lebih baik dan meningkatkan interaksi di antara pemakai dengan komputer. Sajian audio dan visual pada pembelajaran multimedia menjadikan visualisasi lebih menarik. Tampilan multimedia akan membuat siswa lebih leluasa memilih, mensintesa dan mengelaborasi pengetahuan yang ingin dipahaminya. Menurut Malik \& Agarwal (2012, p.470).

Multimedia used in right direction has also succeeded in psychomotor development and strengthening of visual processing of the intended users.

Artinya, multimedia yang digunakan pada arah yang benar juga menyukseskan perkembangan psikomotorik dan memperkuat proses visual para pemakai. Multimedia juga menyediakan peluang bagi siswa untuk mengembangkan teknik pembelajaran sehingga menghasilkan hasil yang maksimal. Pembelajaran berbasis multimedia adalah pembelajaran menggunakan perangkat multimedia sebagai sarana utamanya. Dalam hal ini komputer merupakan komponen utama dalam pembelajaran berbasis multimedia.

Animasi dalam dunia pendidikan berperan sebagai media pembelajaran yang menarik. Animasi merupakan salah satu bentuk visual bergerak yang dapat dimanfaatkan untuk menjelaskan materi pelajaran yang sulit disampaikan secara konvensional juga bertujuan untuk memaksimalkan efek visual dan memberikan interaksi berkelanjutan sehingga pemahaman bahan ajar meningkat. Salah satu perangkat lunak pembuat animasi yang cukup populer pada saat ini adalah Adobe Flash CS 3. Software Adobe Flash CS 3 me-nawarkan berbagai fitur dan kemudahan dalam penggunaannya. Tampilan interface, fungsi, dan pilihan palet yang beragam, serta kumpulan tool yang lengkap sangat membantu dalam pembuatan karya animasi yang menarik.

Materi geometri yang diajarkan di kelas VIII SMP semester II salah satunya adalah bangun ruang sisi datar antara lain meliputi kubus, balok, prisma dan limas. Untuk mempelajari bangun ruang tersebut siswa dihadapkan pada benda-benda yang bersifat abstrak. Panca indera kita tidak akan dapat menangkap adanya titik, garis, rusuk, diagonal bidang, diagonal ruang, bidang diagonal, dsb. Yang dapat ditangkap dengan panca indera adalah visualisasi dari objek-objek tersebut yang berupa model atau gambar. Pada multimedia yang terdiri dari unsur yang meliputi teks, grafik, animasi, audio dan link. Multimedia menggabungkan sepenuhnya teknologi komputer, sistem video dan sistem audio untuk mendapatkan kombinasi yang lebih baik dan meningkatkan interaksi di antara pemakai dengan komputer. Sajian audio dan visual pada pembelajaran multimedia menjadikan visualisasi lebih menarik, didukung dengan animasi untuk memaksimalkan efek visual dan memberikan interaksi berkelanjutan. Tampilan multimedia akan membuat siswa lebih leluasa memilih, mensintesa dan mengelaborasi pengetahuan yang ingin dipahaminya, sehingga kesulitan siswa dapat teratasi.

Penggunaaan media pembelajaran berbasis komputer merupakan salah satu bidang garapan dalam kawasan teknologi pendidikan. Molenda \& Januszewski (2008, 
p.1) mendefinisikan teknologi pendidikan adalah sebagai berikut.

The study and ethical practice of facilitating learning and improving performance by creating, using, and managing appropriate technological process and resources.

Artinya teknologi pendidikan adalah studi dan praktek yang etis untuk memfasilitasi pembelajaran dan meningkatkan kinerja melalui penciptaan, penggunaan, dan pengaturan proses dan sumber daya teknologi.

Menurut Seels dan Richey (1994, p.27), teknologi pendidikan terdiri dari lima kawasan, yaitu kawasan desain, pengembangan, pemanfaatan, pengelolaan, dan penilaian/evaluasi. Kelima kawasan tersebut berhubungan sinergistik, antara kawasan satu dengan yang lain saling melengkapi dalam bidang garapan atau daerah kerjanya. Setiap kawasan memberikan kontribusi terhadap teori maupun penelitian yang digunakan bersama oleh semua kawasan.

Penelitian ini termasuk dalam kawasan pengembangan yang diartikan sebagai proses penterjemah spesifikasi desain ke dalam bentuk fisik. Kawasan ini meliputi pengembangan teknologi cetak, teknologi audio visual, teknologi berbasis komputer dan teknologi terpadu. Kawasan ini mencakup banyak variasi teknologi yang digunakan dalam pembelajaran, namun kawasan ini tidak terlepas dari teori dan praktek yang berhubungan dengan belajar dan desain. Kawasan pengembangan ini membidangi tentang bagaimana secara teori dan praktek suatu sumber belajar dapat dikembangkan dalam bentuk teknologi.

Berdasarkan uraian di atas, banyak hal yang dapat dijadikan sebagai media pembelajaran, khususnya untuk pembelajaran matematika di sekolah. Salah satunya yaitu menggunakan multimedia pembelajaran yang berisikan materi geometri ruang yang disajikan semenarik mungkin. Peran multimedia dalam pembelajaran sangat penting tetapi di SMP Stella Duce 2
Yogyakarta belum tersedia. Maka dari itu peneliti tertarik untuk mengembangkan multimedia pembelajaran geometri ruang pada materi bangun ruang sisi datar untuk siswa SMP kelas VIII di SMP Stella Duce 2 Yogyakarta yang sesuai dan tepat sehingga menambah daya tarik siswa dalam memahami materi pelajaran.

\section{Metode Penelitian}

Penelitian ini menggunakan model penelitian pengembangan atau Research and Development (R\&D) menurut model Alessi \& Trollip (2001, pp.409-410). Adapun bagan langkah-langkah penelitiannya disajikan pada Gambar 1.

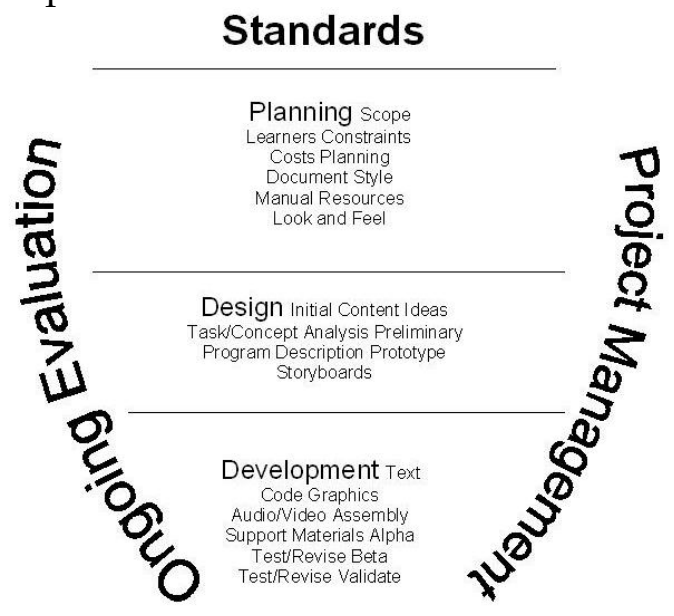

Gambar 1. Langkah-langkah penggunaan Model Alessi \& Trollip (2001, p.410)

Penelitian ini dilakukan di SMP Stella Duce 2 Yogyakarta. Adapun waktu penelitiannya adalah mulai dari bulan Mei sampai dengan Juli tahun 2014. Subjek uji coba penelitian adalah 32 siswa kelas VIII Sasando di SMP Stella Duce 2 Yogyakarta.

Prosedur pengembangan yang dilakukan meliputi tahap perencanaan (planning), desain (design), pengembangan (development). Pada tahap perencanaan meliputi analisis kebutuhan (studi pustaka dan studi lapangan), mengumpulkan dan menentukan sumber-sumber, melakukan brainstorming. Pada tahap desain meliputi pembuatan naskah, flowchart, storyboard dan screen design, mentukan software yang 
digunakan, evaluasi dan revisi bila diperlukan. Pada tahap pengembangan meliputi mengembangkan multimedia pembelajaran dengan menggunakan program program Adobe CS 3, melakukan evaluasi dengan Uji Alfa (evaluasi formatif) kepada 2 orang ahli media dan 2 orang ahli materi, revisi, melakukan evaluasi dengan Uji Beta (evaluasi formatif) kepada 32 orang siswa kelas VIII Sasando SMP Stella Duce 2 Yogyakarta, revisi terakhir, menghasilkan produk, melakukan evaluasi sumatif (uji keefektifan).

Data diperoleh bersumber dari angket dan tes. Data yang bersumber dari angket diperoleh melalui angket dari ahli materi, ahli media, dan tanggapan siswa, terhadap produk yang dikembangkan kemudian dianalisis. Data yang bersumber dari tes diperoleh dari tes kemampuan siswa pada materi bangun ruang sisi datar digunakan untuk mengetahui keefektifan produk pembelajaran yang dihasilkan.

Instrumen yang digunakan untuk mengumpulkan data berupa angket penilaian untuk ahli materi yaitu aspek pembelajaran dan aspek materi, angket untuk ahli media yaitu aspek tampilan, audio visual dan aspek pemrograman dan angket untuk siswa yaitu aspek materi dan aspek media.

Tabel 1. Kisi-kisi Angket Penilaian Pengembangan Multimedia Pembelajaran Matematika oleh Ahli Materi

\begin{tabular}{llll}
\hline No & \multicolumn{1}{c}{ Aspek } & \multicolumn{1}{c}{ Indikator } & No Butir \\
\hline 1 & Rumusan KD & 1 \\
& & Rumusan indikator & 2 \\
& Pembelajar- & Kebenaran materi & 3 \\
& an & Sistematika materi & $4,5,6,7,8,9$ \\
& & Memberikan fokus perhatian & $10,11,12$ \\
& & Kejelasan butir soal & 12,13 \\
& & Tingkat kesulitan & 14 \\
& Umpan balik (feedback) & 15 \\
\hline & Uraian materi & $1,2,3$ \\
& & Organisasi materi & $4,5,6$ \\
& Isi & Pemberian contoh & 7,8 \\
& & Teks & $9,10,11,12,13$ \\
& & Kesesuaian soal & $14,15,16$ \\
\hline
\end{tabular}

Tabel 2. Kisi-kisi Angket Penilaian Pengembangan Multimedia Pembelajaran Matematika oleh Ahli Media

\begin{tabular}{|c|c|c|c|}
\hline No & Aspek & Indikator & No. Butir \\
\hline \multirow{8}{*}{1} & \multirow{8}{*}{ Tampilan } & Komposisi layout & 1 \\
\hline & & $\begin{array}{l}\text { Kesesuaian background } \\
\text { dengan teks }\end{array}$ & 2 \\
\hline & & Komposisi warna & 3 \\
\hline & & Ukuran dalam bentuk teks & $4,5,6$ \\
\hline & & Kesesuaian animasi & 7,8 \\
\hline & & Konsistensi button & 9,10 \\
\hline & & Kesesuaian gambar & 11 \\
\hline & & Kemasan & 12,13 \\
\hline \multirow{3}{*}{2} & \multirow{3}{*}{ Audio Visual } & Kejelasan musik & 1,2 \\
\hline & & Keseuaian musik & 3 \\
\hline & & Kejelasan video & 4 \\
\hline \multirow{4}{*}{3} & \multirow{4}{*}{ Pemrograman } & Kemudahan pengguna & $1,2,3,4,5,6,7$ \\
\hline & & Kinerja navigasi & 8,9 \\
\hline & & Kemudahan pengaturan & 10,11 \\
\hline & & Kinerja sistem operasi & 12,13 \\
\hline
\end{tabular}

Tabel 3. Kisi-kisi Angket Penilaian Pengembangan Multimedia Pembelajaran Matematika oleh Siswa

\begin{tabular}{clc}
\hline No Aspek & \multicolumn{1}{c}{ Indikator } & No Butir \\
\hline \multirow{5}{*}{1 Materi } & Kejelasan judul & 1 \\
& Kejelasan isi & 2 \\
& Pemberian contoh & 3,4 \\
& Kejelasan bahasa & 5 \\
& Kemenasan materi & $6,7,8$ \\
& Pemberian latihan/evaluasi & 10,11 \\
& Tingkat kesulitan & 12 \\
& Umpan balik (feedback) & 13 \\
\hline \multirow{5}{*}{2 Media } & Kejelasan petunjuk & 1 \\
& Kemudahan & 2,3 \\
& Kebebasan memilih & 4 \\
& Weks & 5,6 \\
& Kesesuaian musik/suara & 7 \\
& Kemenarikan animasi, video & $9,10,11$ \\
& dan gambar & 12 \\
& Penggunaan tombol & 13,14 \\
\hline
\end{tabular}

Untuk Uji Keefektifan, data yang diperoleh dari tes kemampuan siswa pada materi bangun ruang sisi datar dianalisis menggunakan analisis statistik deskripstif untuk mengetahui skor rerata pretes dan postes. Selanjutnya data tersebut digunakan untuk mengetahui keefektifan produk 
pembelajaran yang dihasilkan dengan mencari selisih skor postes dan pretes. Hal ini digunakan untuk mengetahui bagaimana peningkatan belajar siswa setelah menggunakan multimedia pembelajaran dengan desain eksperimen before-after (Sugiyono, 2010, p.415). Dalam desain eksperimen ini dicari selisih skor postes dan pretes untuk mengetahui bagaimana peningkatan belajar siswa setelah menggunakan multimedia.

\section{$\mathrm{O} 1 \times \mathrm{O} 2$}

Keterangan:

$\begin{array}{ll}\mathrm{O} 1 & =\text { Jumlah skor pretes } \\ \mathrm{O} 2 & =\text { Jumlah skor postes } \\ \mathrm{X} & =\text { Perlakuan }\end{array}$

Teknik Analisis Data

Data yang bersumber dari angket

Data yang diperoleh melalui angket dari ahli materi, ahli media, dan tanggapan siswa, terhadap produk yang dikembangkan kemudian dianalisis. Hal ini dimaksudkan untuk menggambarkan karakteristik masing-masing data, mempermudah memahami data untuk proses analisis selanjutnya dan digunakan sebagai dasar merevisi produk yang dikembangkan. Langkah-langkah dalam analisis data yang digunakan untuk memberikan kriteria kualitas terhadap produk yang dikembangkan adalah data kuantitatif berupa skor penilaian dari ahli media, ahli materi, dan tanggapan siswa yang diperoleh dari angket dianalisis dengan acuan tabel konversi nilai yang diadaptasi dari Sudijono (2012, pp.329-333).

Tabel 4. Konversi data kuantitatif ke data kualitatif dengan skala 5

\begin{tabular}{ccc}
\hline $\begin{array}{c}\text { Data } \\
\text { Kuantitatif }\end{array}$ & Rentang & $\begin{array}{c}\text { Data } \\
\text { Kualitatif }\end{array}$ \\
\hline 5 & $\mathrm{X}>\mathrm{Xi}+1,50 \mathrm{SDi}$ & Sangat baik \\
4 & $\mathrm{Xi}+0,50 \mathrm{SDi}<\mathrm{X} \leq \mathrm{Xi}+1,50 \mathrm{SDi}$ & Baik \\
3 & $\mathrm{Xi}-0,50 \mathrm{SDi}<\mathrm{X} \leq \mathrm{Xi}+0,50 \mathrm{SDi}$ & Cukup \\
2 & $\mathrm{Xi}-1,50 \mathrm{SDi}<\mathrm{X} \leq \mathrm{Xi}-0,50 \mathrm{SDi}$ & Kurang \\
1 & $\mathrm{X} \leq \mathrm{Xi}-1,50 \mathrm{SDi}$ & Sangat Kurang \\
\hline
\end{tabular}

Keterangan:

$$
\begin{aligned}
\mathrm{Xi} & =\text { rerata ideal } \\
& =\frac{1}{2}(\text { skor max }+ \text { skor min }) \\
\mathrm{Sbi} & =\text { Simpangan baku ideal } \\
& \left.=\frac{1}{6} \text { (skor max }- \text { skor min }\right) \\
\mathrm{X} & =\text { Skor aktual }
\end{aligned}
$$

Berdasarkan rumus tersebut, untuk mengubah data kualitatif diterapkan konversi sebagai berikut.

Skor maksimal ideal $=5$

Skor minimal ideal $=1$

$$
\begin{aligned}
& \mathrm{Xi}=\frac{1}{2}(5+1)=3 \\
& \mathrm{SDi}=\frac{1}{6}(5-1)=0,67
\end{aligned}
$$

a. Skor 5 (Sangat Baik), apabila

$$
=X>3+1,01
$$$$
=\mathrm{X}>3+(1,5 \times 0,67)
$$$$
=X>4,01
$$

b. Skor 4 (Baik), apabila

$=3+(0,5 \times 0,67)<X \leq 4,01$

$=3+0,34<X \leq 4,01$

$=3,34<X \leq 4,01$

c. Skor 3 (Cukup), apabila

$=3-0,34<x \leq 3+0,34$

$=2,66<X \leq 3,34$

d. Skor 2 (Kurang), apabila

$=3-(1,5 \times 0,67)<X \leq 2,66$

$=3-1,01<x \leq 2,66$

$=1,99<X \leq 2,66$

e. Skor 1 (Sangat Kurang) =X $\leq 1,99$

Tabel 5. Pedoman hasil konversi skor ke nilai pada skala 5

\begin{tabular}{ccc}
\hline $\begin{array}{c}\text { Data } \\
\text { Kuantitatif }\end{array}$ & Rentang & Data Kualitatif \\
\hline 5 & $X>4.01$ & Sangat baik \\
4 & $3,34<X \leq 4,01$ & Baik \\
3 & $2,66<X \leq 3,34$ & Cukup \\
2 & $1,99<X \leq 2,66$ & Kurang \\
1 & $X \leq 1,99$ & Sangat Kurang \\
\hline
\end{tabular}

Dalam penelitian ini ditetapkan nilai kelayakan produk minimal "B" dengan kategori "baik", sebagai hasil penilaian baik dari ahli materi, ahli media maupun siswa. Jika hasil penilaian akhir 
secara keseluruhan pada setiap aspek pembelajaran, aspek materi, aspek tampilan dan aspek pemrograman dengan minimal "B" (baik) maka produk hasil pengembangan tersebut sudah layak digunakan. Untuk menghitung skor rata-rata dalam penilaian terhadap produk yang telah dikembangkan digunakan rumus:

$$
X i=\frac{\Sigma x}{n}
$$

Keterangan:

\begin{tabular}{ll}
\hline $\mathrm{Xi}$ & $=$ skor rata-rata \\
$\Sigma x$ & $=$ jumlah skor \\
$n$ & $=$ jumlah responden
\end{tabular}

Untuk mengetahui ketuntasan belajar siswa, peneliti menggunakan nilai minimal "70" sesuai Kriteria Ketuntasan Minimal (KKM) yang digunakan untuk ketuntasan belajar matematika kelas VIII sesuai dengan kebijakan di SMP Stella Duce 2, sehingga apabila siswa dalam uji kompetensi mendapat nilai minimal 70, siswa tersebut dinyatakan sudah mencapai ketuntasan belajar pada materi tersebut.

Data yang Bersumber dari Tes

Data yang diperoleh dari tes kemampuan siswa pada materi bangun ruang sisi datar digunakan untuk mengetahui keefektifan produk pembelajaran yang dihasilkan. Skor tersebut dihitung untuk mengetahui keefektifan perlakuan yang diberikan menggunakan rumus (Meltzer, 2002, p.1260):

$\mathrm{N}$-gain $=\frac{\text { Skor pos tes-Skor pre tes }}{\text { Skor maksimum-Skor pre tes }}$

Keterangan:

$\mathrm{N}$-gain = nilai gain (selisih) yang dinormalkan

Skor maksimum = skor maksimum soal

Skor pretes $\quad=$ rata-rata pretes kelas

Skor postes $\quad=$ rata-rata postes kelas

Bila nilai O2 lebih besar daripada nilai O1, maka metode mengajar tersebut efektif. Nilai ini kemudian diinterpretasikan ke dalam tabel klasifikasi nilai gain (Hake, 1998, p.3) disajikan pada Tabel 6.
Tabel 6. Interpretasi Nilai $<\mathrm{g}>$

\begin{tabular}{cc}
\hline Nilai $<\mathrm{g}>(\mathrm{n})$ & Kriteria \\
\hline $0,71>1,00$ & Baik \\
$0,31>0,70$ & Sedang \\
$0,00>0,30$ & Jelek \\
\hline
\end{tabular}

\section{Hasil Penelitian dan Pembahasan}

Hasil Pengembangan

Pada tahap perencanaan diawali dengan melakukan analisis kebutuhan, kegiatan yang dilakukan adalah studi pustaka dan studi lapangan. Berdasarkan analisis kebutuhan dan deskripsi data survei menunjukan terdapat sejumlah permasalahan dalam pembelajaran matematika, yaitu (1) penggunaan multimedia pembelajaran akan sangat membantu siswa dalam memahami konsep materi secara konkret sehingga tidak abstrak khususnya pada materi bangun ruang sisi datar. (2) sebagian besar (11 orang) guru SMP di Yogyakarta belum pernah merancang atau mengembangkan media pembelajaran berbantuan komputer, (3) saat ini media pembelajaran berbasis komputer cukup maju di beberapa sekolah dan didukung dengan fasilitas yang ada, (4) beberapa guru dari 11 SMP di Yogyakarta belum menggunakan software Adobe Flash CS 3 tetapi masih menggunakan Power Point dan Lectora, (5) metode dan yang biasa digunakan guru dalam pembelajaran matematika yaitu metode diskusi, tanya jawab, kerja kelompok dan pembelajaran dengan menggunakan media pembelajaran berupa power point, (6) sebagian besar siswa kelas VIII masih mengalami kesulitan dalam mempelajari materi bangun ruang sisi datar, terbukti dari hasil rata-rata nilai ulangan harian siswa masih di bawah KKM yaitu 59 dengan batas KKM adalah 70, (7) secara umum siswa kelas VIII Sasando dapat menggunakan komputer atau laptop untuk belajar mandiri, dapat menyalakan dan mematikannya tanpa bantuan orang lain dan masing-masing siswa mempunyai komputer atau laptop di rumah, (8) laboratorium belum digunakan secara optimal 
untuk mendukung pembelajaran matematika. Dari hasil analisis kebutuhan pada tahap perencanaan di atas perlu dikembangkan multimedia pembelajaran matematika pada materi bangun ruang sisi datar untuk siswa SMP kelas VIII.

Pada tahap selanjutnya setelah tahap perencanaan adalah tahap desain produk multimedia. Kegiatan yang dilakukan dalam tahap ini yaitu pembuatan naskah, storyboard, flowchart, screen design, dan menentukan software yang digunakan.

Penulisan naskah didahului dengan analisis materi terhadap Kurikulum Tingkat Satuan Pendidikan (KTSP) untuk mata pelajaran matematika SMP materi bangun ruang sisi datar (BRSD). Berikut ini tabel hasil dari analisis materi sesuai dengan silabus dalam Kurikulum Tingkat Satuan Pendidikan (KTSP).

Tabel 7. Hasil Analisis Materi Bangun Ruang Sisi Datar

\begin{tabular}{|c|c|c|c|}
\hline No & Kompetensi Dasar & Indikator & Materi \\
\hline 1 & $\begin{array}{l}\text { Mengidentifikasi sifat-sifat kubus, } \\
\text { balok, prisma dan limas serta bagian- } \\
\text { bagiannya }\end{array}$ & $\begin{array}{l}\text { Menyebutkan unsur-unsur kubus, balok, } \\
\text { prisma, dan limas: rusuk, bidang sisi, } \\
\text { diagonal bidang, diagonal ruang, bidang } \\
\text { diagonal. }\end{array}$ & $\begin{array}{l}\text { Kubus. Balok, } \\
\text { Prisma, dan Limas }\end{array}$ \\
\hline 2 & $\begin{array}{l}\text { Membuat jaring-jaring kubus, balok, } \\
\text { prisma dan limas }\end{array}$ & $\begin{array}{l}\text { Membuat dan mengetahui alternatif } \\
\text { jaring-jaring kubus, balok, prisma tegak } \\
\text { dan limas }\end{array}$ & $\begin{array}{l}\text { Kubus. Balok, } \\
\text { Prisma, dan Limas }\end{array}$ \\
\hline 3 & $\begin{array}{l}\text { Menghitung luas permukaan dan } \\
\text { volume kubus, balok, prisma dan } \\
\text { limas }\end{array}$ & $\begin{array}{l}\text { a. Menghitung luas permukaan kubus, } \\
\text { balok, prisma dan limas } \\
\text { b. Menghitung volume kubus, balok, } \\
\text { prisma dan limas. }\end{array}$ & $\begin{array}{l}\text { Kubus. Balok, } \\
\text { Prisma, dan Limas }\end{array}$ \\
\hline
\end{tabular}

Dari hasil analisis materi diperoleh 4 sub materi yang akan disampaikan dalam media pembelajaran yaitu Kubus, Balok, Prisma dan Limas, dan review video tentang peta konsep materi. Setelah materi yang akan dibahas dalam multimedia pembelajaran ditentukan, langkah selanjut- nya adalah penentuan teori belajar yang digunakan yaitu teori kognitif, behavioristik, dan teori konstruktivistik untuk diterapkan dalam multimedia pembelajaran. Berdasarkan naskah yang ditulis CD multimedia pembelajaran ini meliputi 3 bagian, yaitu:

Tabel 8. Isi CD Multimedia Pembelajaran

\begin{tabular}{lll}
\hline Bagian & \multicolumn{1}{c}{ Sub bagian } & \multicolumn{1}{c}{ Isi } \\
\hline Awal & Intro & $\begin{array}{l}\text { Animasi ucapan selamat datang pada multimedia pembelajaran dan dilanjutkan tes } \\
\text { kemampuan awal. }\end{array}$ \\
\hline Isi & Kompetensi Dasar & $\begin{array}{l}\text { Kompetensi dasar dan indikator berisi tujuan yang harus dicapai siswa setelah } \\
\text { mempelajari materi. }\end{array}$ \\
& Materi dan Simulasi & Materi yang disajikan disajikan dengan simulasi, latihan dan contoh soal. \\
1) Kubus & a) Pada materi Kubus berisi unsur-unsur, sifat-sifat, jaring-jaring, luas dan volume. \\
2) Balok & b) Pada materi Balok berisi unsur-unsur, sifat-sifat, jaring-jaring, luas dan volume. \\
3) Prisma & c) Pada materi Prisma berisi unsur-unsur, sifat-sifat, jaring-jaring, luas dan volume. \\
4) Limas & d) Pada materi Limas berisi unsur-unsur, sifat sifat, jaring-jaring, luas dan volume. \\
& Review Video & Berisi peta konsep materi bangun ruang sisi datar. \\
& Rangkuman & Berisi rangkuman semua materi bangun ruang sisi datar. \\
& Evaluasi & Berisi soal-soal pemahaman siswa setelah mempelajari materi pada multimedia \\
& Gembelajaran.
\end{tabular}


Setelah mengetahui bagian-bagian dari CD pembelajaran, langkah selanjutnya adalah membuat flowchart. Flowchart digunakan untuk menggambarkan keseluruhan alur pembelajaran dalam CD pembelajaran yang akan dikembangkan. Kemudian dilanjutkan dengan pembuatan storyboard. Setelah melewati tahapan penulisan naskah, pembuatan flowchart, dan storyboard, dilanjutkan dengan perancangan screen design. Screen design meliputi pewarnaan background, navigasi, animasi dan teks.

Software yang akan digunakan dalam pembuatan multimedia pembelajaran ini adalah Adobe Flash CS 3 karena software ini memiliki banyak fitur pendukung dan diharapkan akan terwujud sebuah aplikasi media pembelajaran yang atraktif dan menarik secara visual bagi siswa. Juga program pendukung seperti Adobe Photosop CS 3, Corel Draw X6, Blender, Adobe Illustrator, 3D Max.

Tahap pengembangan merupakan tahap lanjutan dari tahap desain. Adapun kegiatan yang dilakukan pada tahap pengembangan adalah: (a) mengembangkan multimedia pembelajaran dengan menumpulkan bahan-bahan berupa tiga macam buku Matematika untuk kelas VIII terbitan Erlangga, BSE dan Yudhistira. Hal ini mempunyai tujuan karena buku tersebut memuat penjelasan materi yang sesuai dengan konteks pembelajaran dan sangat berguna sebagai landasan awal untuk mendesain pesan pada awal multimedia, selanjutnya video produksi Wahana Aplikasi Pendidikan dan Informasi yang Baik (WAPIK). Video tersebut merupakan bagian dari Program Basic Education Capacity Trust Fund (Bank Dunia) yang didanai oleh uni Eropa dan Pemerintah Kerajaan Belanda. Kemudian sumber belajar dari website rumah belajar (http://belajar. kemdiknas.go.id/) dipilih karena sesuai dengan konteks materi pelajaran. Penggabungan bagian-bagian multimedia tersebut menggunakan program utama Adobe Flash CS 3 dan juga program pendukung seperti Adobe Photosop CS 3, Corel Draw X6,
Blender, Adobe Illustrator, 3D Max dan (b) mengemas produk awal ke dalam CD/flash disk, untuk kemudian digandakan pada setiap komputer yang ada di laboratorium SMP Stella Duce 2 Yogyakarta.

Pada tahap Uji Alfa dilakukan evaluasi formatif dengan penggunaan Expert Judgment sebanyak 2 orang ahli media dan 2 orang ahli materi. Hasil evaluasi dari ahli materi dan ahli media dijadikan acuan untuk memperbaiki produk multimedia pembelajaran matematika sebelum dilakukan Uji Beta. Untuk melakukan evaluasi dengan Uji Beta, uji coba produk dan uji keefektifan diberikan kepada 32 orang siswa kelas VIII Sasando SMP Stella Duce 2 Yogyakarta.

\section{Hasil Uji Coba Produk}

Analisis Data Uji Alfa

Validasi oleh Ahli Materi

Validasi ahli materi (dosen) dilakukan dalam 2 tahap yang terdiri atas 2 aspek yaitu aspek pembelajaran dan isi. Pada validasi tahap pertama, untuk aspek pembelajaran terdapat 12 aspek penilaian, 1 aspek mendapat skor 3 (cukup), 9 aspek mendapat skor 4 (baik), dan 2 aspek mendapat skor 5 (sangat baik). Hasil perhitungan menunjukan rerata pada aspek pembelajaran adalah 4,1 (sangat baik). Kemudian untuk aspek isi terdapat 18 aspek penilaian, 1 aspek mendapat skor 2 (kurang), 12 aspek mendapat skor 3 (cukup), dan 5 aspek mendapat skor 4 (baik). Rerata pada aspek isi adalah 3,2 (cukup).

Berdasarkan perhitungan keseluruhan, maka rerata hasil validasi oleh ahli materi adalah 3,65. Hasil ini menunjukan bahwa kelayakan materi pada multimedia ini adalah "baik", namun terlebih dahulu dilakukan Revisi Awal sesuai dengan yang disarankan. Tampilan hasil penilaian oleh ahli materi disajikan pada Gambar 2.

Pada validasi tahap kedua, untuk aspek pembelajaran terdapat 12 aspek penilaian, 5 aspek mendapat skor 4 (baik), dan 7 aspek mendapat skor 5 (sangat baik). Hasil perhitungan menunjukan rerata pada 
aspek pembelajaran adalah 4,58 (sangat baik). Kemudian untuk aspek isi terdapat 18 aspek penilaian, 14 aspek mendapat skor 4 (baik), dan 4 aspek mendapat skor 5 (sangat baik). Rerata pada aspek isi adalah 4,22 (sangat baik).

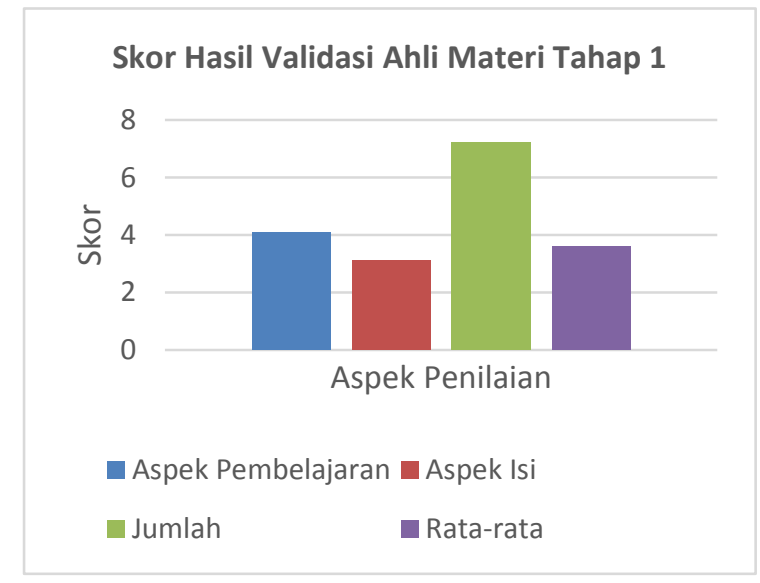

Gambar 2. Skor Hasil Validasi Ahli Materi Tahap 1

Berdasarkan perhitungan keseluruhan, rerata hasil validasi oleh ahli materi adalah 4,4. Hasil ini menunjukan bahwa kelayakan materi pada multimedia ini adalah "Sangat Baik", sehingga dapat dilanjutkan ke tahap uji beta. Tampilan hasil penilaian oleh ahli materi disajikan pada Gambar 3.

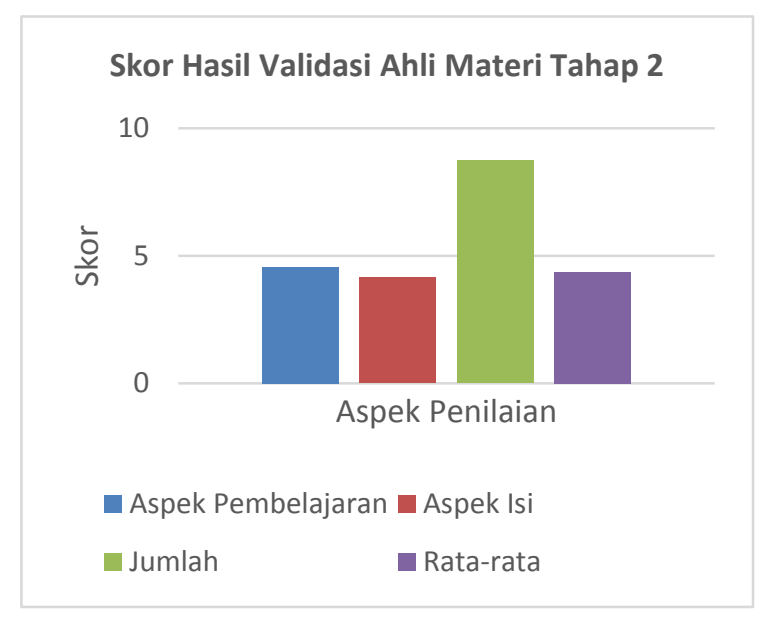

Gambar 3. Skor Hasil Validasi Ahli Materi Tahap 2

Validasi materi oleh ahli materi (guru matematika) juga dilakukan secara 2 tahap yang terdiri atas 2 aspek, yaitu aspek pembelajaran dan isi. Pada validasi tahap pertama aspek pembelajaran terdapat 12 aspek penilaian, 2 aspek mendapat skor 3 (cukup), dan 10 aspek mendapat skor 4 (baik). Hasil perhitungan menunjukan rerata pada aspek pembelajaran adalah 3,83 (baik). Kemudian untuk aspek isi terdapat 18 aspek penilaian, 5 aspek mendapat skor 3 (cukup), 12 aspek mendapat skor 4 (baik), dan 1 aspek mendapat skor 5 (sangat baik). Rerata pada aspek isi adalah 3,77 (baik).

Berdasarkan perhitungan keseluruhan, rerata hasil validasi oleh ahli materi adalah 3,8. Hasil ini menunjukan bahwa kelayakan materi pada multimedia ini adalah "baik", namun terlebih dahulu dilakukan Revisi Awal sesuai dengan yang disarankan.

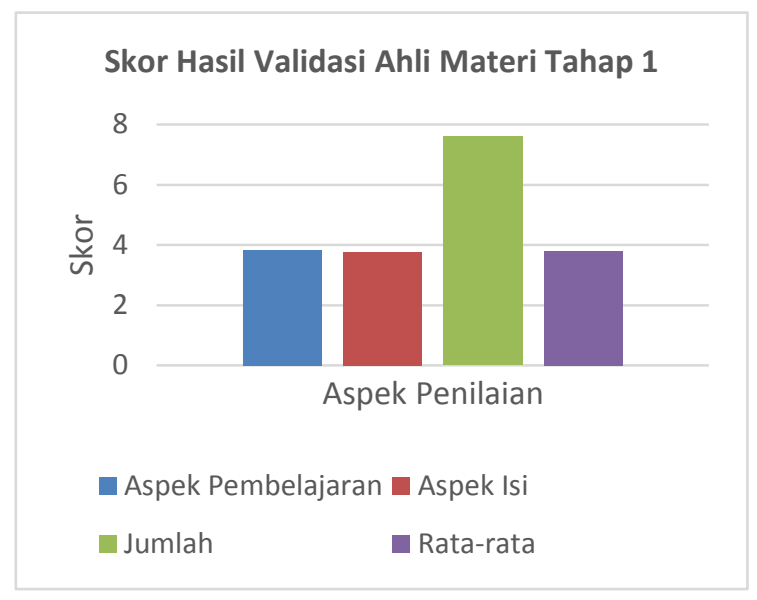

Gambar 4. Skor Hasil Validasi Ahli Materi Tahap 1

Pada validasi tahap kedua, untuk aspek pembelajaran terdapat 12 aspek penilaian, 4 aspek mendapat skor 4 (baik), dan 8 aspek mendapat skor 5 (sangat baik). Hasil perhitungan menunjukan rerata pada aspek pembelajaran adalah 4,67 (sangat baik). Kemudian untuk aspek isi terdapat 18 aspek penilaian, 7 aspek mendapat skor 4 (baik), dan 11 aspek mendapat skor 5 (sangat baik). Rerata pada aspek isi adalah 4,64 (sangat baik).

Berdasarkan perhitungan keseluruhan, rerata hasil validasi oleh ahli materi adalah 4,64. Hasil ini menunjukan bahwa kelayakan materi pada multimedia ini adalah "sangat baik", sehingga dapat dilanjutkan ke tahap Uji Beta. 


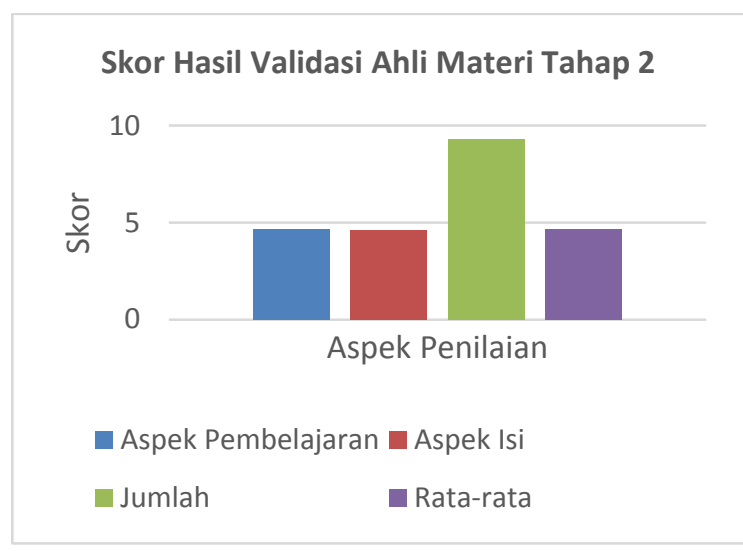

Gambar 5. Skor Hasil Validasi Ahli Materi Tahap 2

\section{Validasi oleh Ahli Media}

Validasi ahli media (dosen) dilakukan dalam 2 tahap yang terdiri atas 3 aspek yaitu aspek tampilan, audio visual dan pemrograman. Pada validasi tahap pertama aspek tampilan terdapat 10 aspek penilaian, 5 aspek mendapat skor 3 (cukup), dan 6 aspek mendapat skor 4 (baik). Hasil perhitungan menunjukan rerata pada aspek tampilan adalah 3,5 (baik). Untuk aspek audio visual terdapat 6 aspek penilaian, 1 aspek mendapat skor 2 (kurang), 4 aspek mendapat skor 3 (cukup), dan 1 aspek mendapat skor 4 (baik). Hasil perhitungan menunjukan rerata pada aspek audio visual adalah 3,1 (cukup). Kemudian untuk aspek pemrograman terdapat 13 aspek penilaian, 8 aspek mendapat skor 3 (baik), dan 5 aspek mendapat skor 4 (baik). Rerata pada aspek pemrograman adalah 3,4 (baik).

Berdasarkan perhitungan keseluruhan, rerata hasil validasi oleh ahli media adalah 3,4. Hasil ini menunjukan bahwa kelayakan materi pada multimedia ini adalah "baik", namun terlebih dahulu dilakukan Revisi Awal sesuai dengan yang disarankan. Tampilan hasil penilaian oleh ahli materi disajikan pada Gambar 6 .

Pada validasi tahap kedua, untuk aspek tampilan terdapat 10 aspek penilaian, 6 aspek mendapat skor 4 (baik), dan 4 aspek mendapat skor 5 (sangat baik). Hasil perhitungan menunjukan rerata pada aspek tampilan adalah 4,4 (sangat baik).
Untuk aspek audio visual terdapat 6 aspek penilaian, 3 aspek mendapat skor 4 (baik), dan 3 aspek mendapat skor 5 (sangat baik). Hasil perhitungan menunjukan rerata pada aspek audio visual adalah 4,5 (sangat baik). Kemudian untuk aspek pemrograman terdapat 13 aspek penilaian, 6 aspek mendapat skor 4 (baik), dan 7 aspek mendapat skor 5 (sangat baik). Rerata pada aspek pemrograman adalah 4,54 (sangat baik).

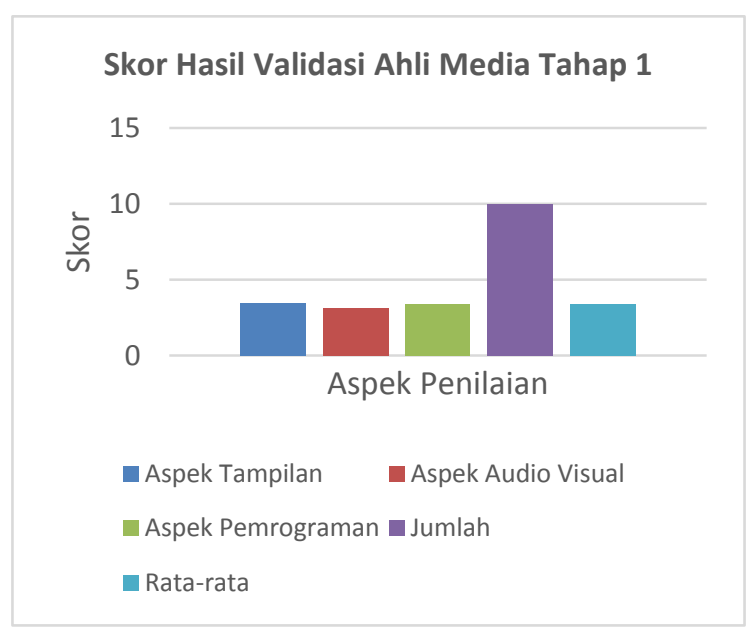

Gambar 6. Skor Hasil Validasi Ahli Media Tahap 1

Berdasarkan perhitungan keseluruhan, rerata hasil validasi oleh ahli media adalah 4,48. Hasil ini menunjukan bahwa kelayakan materi pada multimedia ini adalah "sangat baik", sehingga dapat dilanjutkan ke tahap Uji Beta. Tampilan hasil penilaian oleh ahli materi disajikan pada Gambar 7.

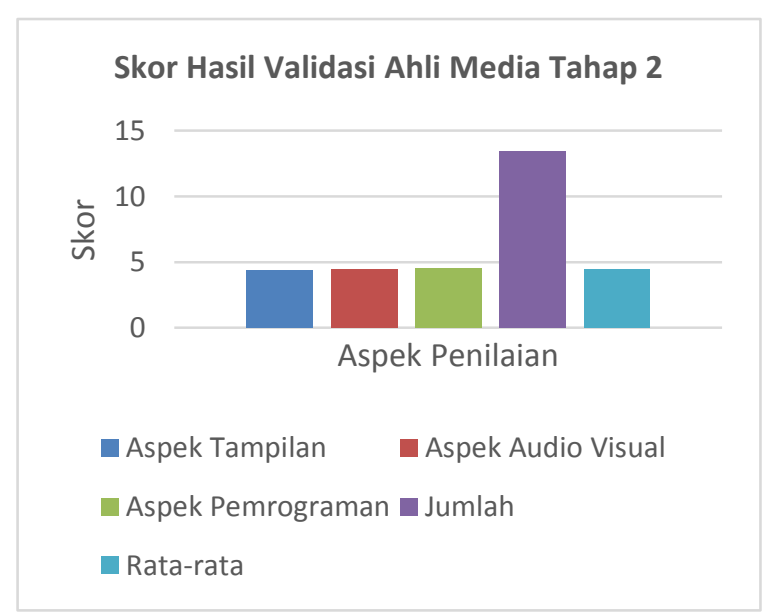

Gambar 7. Skor Hasil Validasi Ahli Media Tahap 2 
Validasi materi yang kedua oleh ahli media (dosen) juga dilakukan secara 2 tahap yang terdiri atas yang terdiri atas 3 aspek yaitu aspek tampilan, audio visual dan pemrograman. Pada validasi tahap pertama aspek tampilan terdapat 10 aspek penilaian, 2 aspek mendapat skor 2 (kurang), 1 aspek mendapat skor 3 (cukup), 5 aspek mendapat skor 4 (baik), dan 1 aspek mendapat skor 5 (sangat baik). Hasil perhitungan menunjukan rerata pada aspek tampilan adalah 3,7 (baik). Untuk aspek audio visual terdapat 6 aspek penilaian, 6 aspek mendapat skor 4 (baik). Hasil perhitungan menunjukan rerata pada aspek audio visual adalah 4 (baik). Kemudian untuk aspek pemrograman terdapat 13 aspek penilaian, 1 aspek mendapat skor 2 (kurang), 1 aspek mendapat skor 3 (cukup), 9 aspek mendapat skor 4 (baik), dan 2 aspek mendapat skor 5 (sangat baik). Rerata pada aspek pemrograman adalah 3,92 (baik).

Berdasarkan perhitungan keseluruhan, rerata hasil validasi oleh ahli media adalah 3,87. Hasil ini menunjukan bahwa kelayakan materi pada multimedia ini adalah "baik", namun terlebih dahulu dilakukan Revisi Awal sesuai dengan yang disarankan. Tampilan hasil penilaian oleh ahli materi disajikan pada Gambar 8.

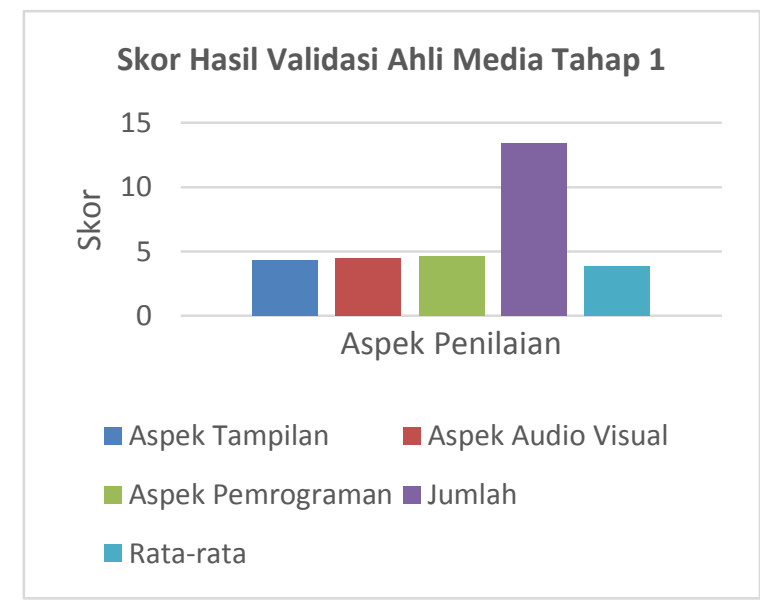

Gambar 8. Skor Hasil Validasi Ahli Media Tahap 1

Pada validasi tahap kedua, untuk aspek tampilan terdapat 10 aspek penilaian, 5 aspek mendapat skor 4 (baik), dan 5 aspek mendapat skor 5 (sangat baik). Hasil perhitungan menunjukan rerata pada aspek tampilan adalah 4,5 (sangat baik). Untuk aspek audio visual terdapat 6 aspek penilaian, 3 aspek mendapat skor 4 (baik), dan 3 aspek mendapat skor 5 (sangat baik). Hasil perhitungan menunjukan rerata pada aspek audio visual adalah 4,5 (sangat baik). Kemudian untuk aspek pemrograman terdapat 13 aspek penilaian, 5 aspek mendapat skor 4 (baik), dan 8 aspek mendapat skor 5 (sangat baik). Rerata pada aspek pemrograman adalah 4,61 (sangat baik).

Berdasarkan perhitungan keseluruhan, rerata hasil validasi oleh ahli media adalah 4,5. Hasil ini menunjukan bahwa kelayakan materi pada multimedia ini adalah "sangat baik", sehingga dapat dilanjutkan ke tahap Uji Beta.

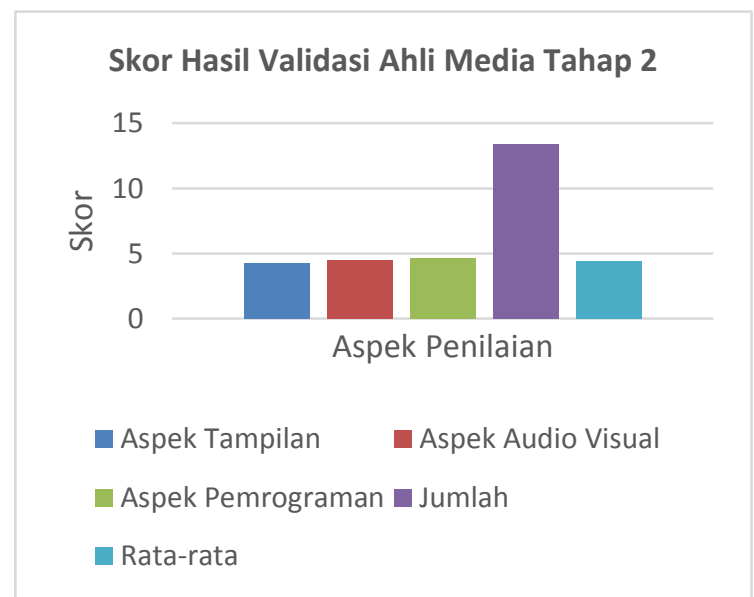

Gambar 9. Skor Hasil Validasi Ahli Media Tahap 2

\section{Analisis Data Uji Beta}

Berdasarkan data, diketahui bahwa rerata hasil penilaian pada Uji Beta adalah 4,03 (sangat baik). Terdapat 2 aspek penilaian, yaitu aspek materi dan aspek media. Pada aspek materi terdapat 13 aspek yang dinilai oleh siswa, 5 aspek dinilai berkategori "baik" dan 8 aspek dinilai "sangat baik". Kelima aspek yang dinilai siswa baik adalah: (a) ketepatan dalam penjelasan materi konseptual; (b) ketepatan dalam penjelasan materi praktis, kesesuaian latihan/evaluasi dengan materi; (c) kesesuaian latihan/evaluasi dengan 
materi; (d) tingkat kesulitan soal latihan/ evaluasi; (e) ketepatan pemberian feedback/ umpan balik atas jawaban siswa.

Kemudian kedelapan aspek yang dinilai sangat baik adalah: (a) kejelasan judul program; (b) kejelasan isi materi; (c) kejelasan contoh yang disertakan; (d) kecukupan contoh yang disertakan; (e) kejelasan bahasa yang digunakan, (f) variasi jenis penyampaian informasi/materi, (g) kemenarikan materi dalam memotivasi siswa,

(h) kejelasan petunjuk dalam mengerjakan soal latihan/evaluasi. Hasil penilaian terhadap multimedia pembelajaran matematika bangun ruang sisi datar disajikan pada Gambar 10.

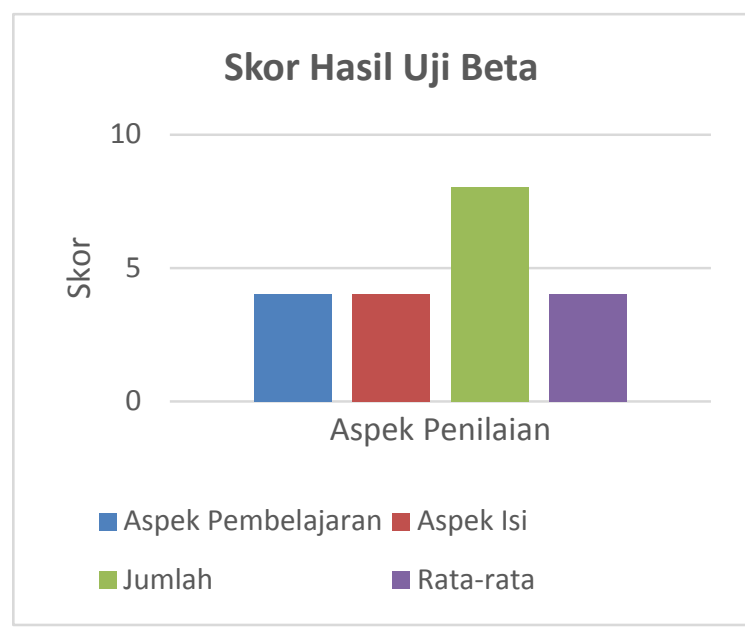

Gambar 10. Skor Hasil Uji Beta

Sehingga hasil penilaian siswa terhadap multimedia pembelajaran matematika bangun ruang sisi datar pada Uji Beta adalah sangat baik. Hal ini dibuktikan dengan hasil rerata yang mencapai 4,03 (sangat baik). Berdasarkan hasil ini, multimedia pembelajaran matematika bangun ruang sisi datar dapat dinyatakan layak digunakan dalam pembelajaran dan proses Uji Beta dapat dilanjutkan ke tahap berikutnya, tentu dengan terlebih dahulu melakukan Revisi Akhir sesuai komentar dan saran siswa.

\section{Analisis Data Uji Keefektifan}

Selanjutnya pada tahap ini dilaksanakan pretes dan postes yang bertujuan untuk mengetahui keefektifan penggunaan multimedia oleh siswa dalam pembelajaran. Hasil analisis pada tabel menunjukan bahwa terdapat perbedaan antara sebelum dan sesudah beajar menggunakan multimedia. Perbedaan tersebut ditunjukkan pada rerata pretes dan postes. Pada pretes diperoleh rerata 4,96, sedangkan pada postes diperoleh rerata 7,4 . Selisih antara rerata pretes dan postes ini disebut dengan istilah gain score yaitu dengan nilai 0,48 yang mempunyai kriteria sedang.

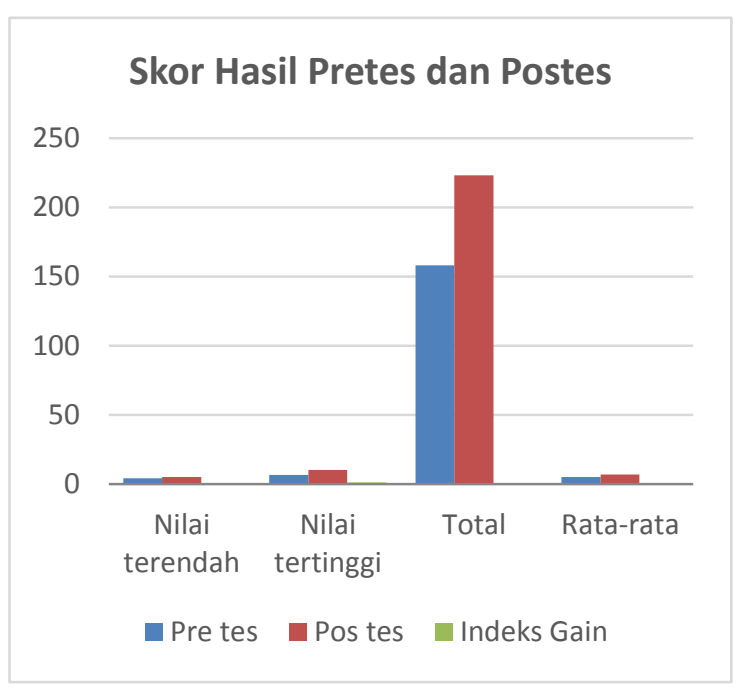

Gambar 11. Skor Hasil Uji Keefektifan

Berdasarkan hasil gain score tersebut, diketahui bahwa terjadi peningkatan hasil belajar siswa setelah belajar menggunakan multimedia. Selain gain score terdapat pula perbedaan antara nilai tertinggi dan nilai terendah pada saat pretes dan postes. Nilai tertinggi pada saat pretes adalah 6,5 dan nilai terendahnya adalah 3 . Kemudian nilai tertinggi saat postes adalah 10, sedangkan nilai terendahnya adalah 5 .

Berdasarkan analisis hasil postes dan pretes, diketahui pula tingkat ketuntasan belajar siswa. Ketuntasan mengacu pada KKM mata pelajaran matematika, yaitu 70 . Pada saat pretes $0(0 \%)$ siswa dinyatakan tuntas, sedangkan $32 \quad(100 \%)$ siswa dinyatakan tidak tuntas. Kemudian pada saat dilaksanakan postes, 24 (75\%) siswa dinyatakan tuntas, sedangkan $8(25 \%)$ siswa dinyatakan tidak tuntas. Tampilan ketuntasan belajar siswa ini disajikan pada Gambar 12. 


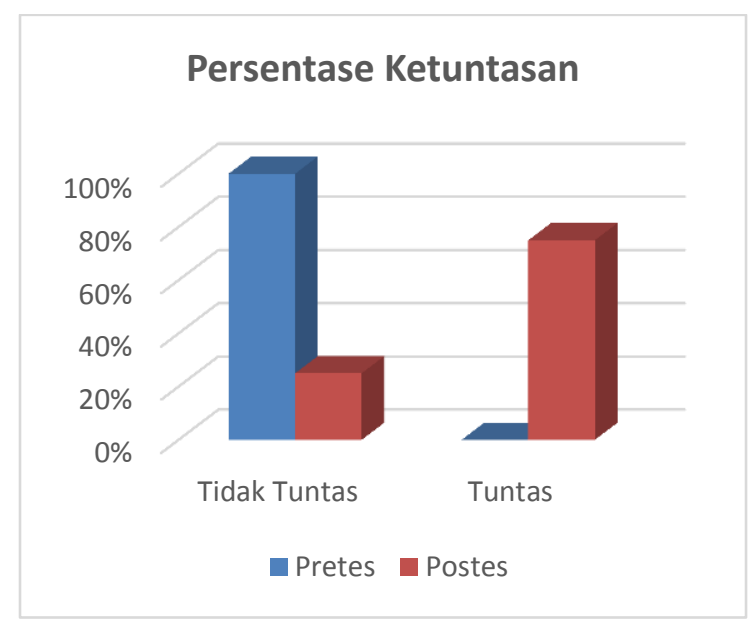

Gambar 12. Persentase Ketuntasan Siswa

Berdasarkan uraian mengenai gain score dan ketuntasan belajar siswa, dapat disimpulkan bahwa multimedia pembelajaran matematika bangun ruang sisi datar dapat meningkatkan pencapaian hasil belajar siswa, sehingga tuntas dalam belajar. Pencapaian ini menunjukkan pula bahwa multimedia pembelajaran matematika bangun ruang sisi datar efektif digunakan dalam pembelajaran.

\section{Simpulan dan Saran}

Simpulan

Produk multimedia yang dihasilkan adalah multimedia pembelajaran matematika pada materi bangun ruang sisi datar, SK ke 5, KD ke 5.1, 5.2, dan 5.3 untuk siswa SMP kelas VIII pada semester 2/ genap. Multimedia pembelajaran ini secara umum terdiri atas halaman pembuka, pendahuluan, menu utama, materi dan latihan, evaluasi, games, profil pengembang dan halaman petunjuk penggunaan. Untuk teori belajar yang digunakan adalah teori belajar kognitif, behavioristik dan konstruktivistik.

Kualitas multimedia pembelajaran matematika bangun ruang sisi datar dinyatakan layak untuk digunakan dalam pembelajaran: (a) penilaian aspek pembelajaran 4,625 (sangat baik); (b) penilaian aspek isi 4,41 (sangat baik); (c) penilaian aspek tampilan 4,45 (sangat baik); (d) pe- nilaian aspek audio visual 4,5 (sangat baik); (e) penilaian aspek pemrograman 4,575 (sangat baik). Berdasarkan pada hasil penilaian ahli materi 4,4 (sangat baik) dan 4,64 (sangat baik), penilaian ahli media 4,48 (sangat baik) dan 4,5 (sangat baik), penilaian 32 siswa pada Uji Beta sebesar 4,03 (sangat baik).

Multimedia pembelajaran matematika bangun ruang sisi datar dinyatakan efektif meningkatkan hasil belajar siswa. Hal ini dibuktikan dengan selisih antara rerata pretes dan postes ini disebut dengan istilah gain score, yaitu dengan nilai 0,48 yang mempunyai kriteria sedang. Selain gain score terdapat pula perbedaan antara nilai tertinggi dan nilai terendah pada saat pretes dan postes. Nilai tertinggi pada saat pretes adalah 6,5 dan nilai terendahnya adalah 3. Kemudian nilai tertinggi saat postes adalah 10 , sedangkan nilai terendahnya adalah 5 .

Terdapat peningkatan ketuntasan belajar siswa setelah menggunakan multimedia pembelajaran matematika bangun ruang sisi datar dengan rerata pretes 4,96 dan postes diperoleh rerata 7,4. Pencapaian KKM siswa pada saat pretes dinyatakan tidak tuntas $100 \%$, sedangkan pada saat postes dinyatakan tuntas $75 \%$.

\section{Saran}

Beberapa saran untuk memanfaatkan multimedia pembelajaran ini adalah: (a) bagi siswa hendaknya terlebih dahulu mengetahui urutan kegiatan pembelajaran dan cara menggunakan multimedia pembelajaran matematika ini; (b) bagi guru agar efektif menggunakan multimedia untuk belajar setelah disesuaikan terlebih dahulu dengan waktu belajar, tujuan belajar, dan strategi pembelajaran matematika bangun ruang sisi datar yang digunakan sehingga pembelajaran tidak lagi berpusat pada guru (teacher center); dan (c) bagi sekolah hendaknya sarana untuk belajar melalui multimedia ini perlu dilengkapi seperti speaker aktif dan agar terus dijaga, diperhatikan untuk perawatannya; (d) 
multimedia pembelajaran ini tidak terbatas pada kegiatan pembelajaran tatap muka saja melainkan dapat dijadikan sumber belajar mandiri.

\section{Daftar Pustaka}

Adams, D. \& Hamm, M. (2010). Demystify math, science and technology. Creativity, innovation and problem solving. Lanham, USA: Rowman \& Littlefield Publisher, Inc.

Alessi, S.M. \& Trollip, S.R. (2001). Multimedia for learning: methods and development. 3nd ed. Needham Heights, USA: Pearson

Barmby, P., et. al. (2009). Primary mathematics: teaching for understanding. London, England: Mc Graw Hill.

Hake, R. R. (1998). Interactive-engagement vs traditional methods: A six-thousand-student survey of mechanics test data for introductory phsyics course. The American Journal of Physics Research 66, 64-74.

Malik, S. \& Agarwal, A. (2012). Use of multimedia as a new educational technology tool-a study. International Journal of Information and Education Technology, Vol. 2, No. 5, October 2012.

Meltzer, D. E. (2002). The Relationship Between Mathematics Preparation and Conceptual Learning Gains In Physics: A Possible "Hidden Variable" In Diagnostic Pretest Scores. Diambil pada tanggal 20 Januari 2014, dari people.physics.tamu.
edu/toback/TeachingArticle/Meltz er_AJP.pdf

Miller, P.H. (2012). Theories of development psychology. Fifth Edition. New York, USA: Worth Publishers.

Molenda, M. \& Januszewski, A. (2008). Educational technology: a definition with commentary. New York, USA: Taylor \& Francis Group, LLC.

Seels, B. B. \& Richey, C. R. (1994). Instructional technology: Definition and domains of the field. Washington, USA: AECT.

Sudijono, A. (2012). Pengantar Evaluasi Pendidikan. Jakarta, Indonesia: PT. Raja Grafindo Persada.

Sudjana, N. \& Rivai, A. (2011). Media pengajaran (penggunaan dan pembuatannya). Bandung, Indonesia: Sinar Baru Algesindo.

Sugiyono. (2010). Metode penelitian pendidikan pendekatan kuantitatif, kualitatif dan RED. Bandung, Indonesia: Alfabeta.

Surjono, H. D. (1995). Pengembangan Computer-Assisted Instruction (CAI) untuk pelajaran elektronika. Jurnal Kependidikan. No. 2 (XXV): 95-106.

Sutopo, A. H. (2003). Multimedia interaktif flash. Yogyakarta, Indonesia: Graha Ilmu.

Suwaji, U. T. (2008). Permasalahan pembelajaran geometri ruang SMP dan alternatif pemecahannya. Yogyakarta: PPPTK Matematika. 